\title{
PEMBERDAYAAN IBU PKK MELALUI PEMBUATAN JAMU HERBAL UNTUK MENINGKATKAN SISTEM IMUN TUBUH DI DESA ALUE SENTANG KABUPATEN ACEH TAMIANG
}

\author{
Fitriani $^{1}$, Andri Yusman Persada ${ }^{2}$ Juliati $^{3}$, Yulina Ismida ${ }^{4}$ \\ 1,2)Program Studi Biologi, Fakultas Teknik Universitas Samudra \\ 3)Program Studi PGSD, Fakultas Keguruan dan Ilmu Pendidikan Universitas Samudra \\ 4)Program Studi Teknik Sipil, Fakultas Teknik Universitas Samudra \\ fitriani@unsam.ac.id
}

\begin{abstract}
Covid 19 is a disease caused by SARS-CoV-2 or known as a virus that can cause pneumonia, multi-organ failure, and death. Therefore, alternative efforts are needed to increase the body's immune system to prevent viral infections in the body. One effort that can be made is to empower Alue Sentang Village people to make and consume herbal herbs, which can increase endurance. Besides, it also increases the role and function of universities, Covid 19 volunteers, and village officials in accelerating and expanding the adoption of innovations in making herbal medicine to support the government in breaking the chain of the spread of Covid 19. The methods used in this activity are the direct approach method, lectures, and practice. The approach method was carried out by listing the problems faced by Alue Sentang Village people regarding the Covid 19 attack. The lecture method was carried out by providing information to the community, Covid 19 volunteers, and village officials about the advantages and benefits of herbal medicine in improving the immune system to prevent and overcome Covid infection. 19. The practical method is carried out by providing training in making herbal herbs, which increases the immune system. The results achieved were the increased understanding and skills of PKK Alue Sentang Village women about making Herbal herbs to improve the immune system to control and prevent Covid-19.
\end{abstract}

Keywords: Alue Sentang, Covid 19, herbal medicine, Relawan Covid

\begin{abstract}
Abstrak
Covid 19 merupakan penyakit yang disebabkan oleh SARS-CoV-2 atau dikenal dengan corana virus yang dapat mengakibatkan pneumonia, kegagalan multiorgan, dan kematian. Oleh karena itu diperlukan upaya alternatif untuk meningkatkan sistem imun tubuh sehingga dapat mencegah terjadinya infeksi virus dalam tubuh. Salah satu upaya yang dapat dilakukan yaitu dengan memberdayakan masyarakat Desa Alue Sentang untuk membuat dan mengkonsumsi jamu herbal yang mempunyai potensi untuk meningkatkan daya tahan tubuh. Selain itu juga meningkatkan peran dan fungsi perguruan tinggi, relawan Covid 19, dan aparatur desa dalam mempercepat dan memperluas adopsi inovasi pembuatan jamu herbal untuk mendukung pemerintah dalam memutuskan rantai penyebaran covid 19. Metode yang digunakan yaitu metode pendekatan langsung, ceramah dan praktik. Metode pendekatan ini dilakukan untuk mendata permasalahan yang dihadapi oleh masyarakat. Metode ceramah dilakukan dengan memberikan informasi kepada masyarakat, relawan Covid 19 dan aparatur desa tentang keunggulan dan manfaat jamu herbal dalam meningkatkan sistem imum sehingga dapat mencegah dan menanggulangi infeksi Covid 19. Metode praktik dilakukan dengan memberikan pelatihan pembuatan jamu herbal yang berperan dalam meningkatkan sistem imun. Hasil yang dicapai yaitu meningkatnya pemahaman dan keterampilan Ibu PKK Desa Alue Sentang tentang pembuatan jamu herbal untuk meningkatkan sistem imum dalam upaya pennggulangan dan pencegahan covid-19
\end{abstract}

Kata kunci: Alue Sentang, Covid 19, Jamu Herbal, Relawan Covid

MARTABE : Jurnal Pengabdian Masyarakat | 240 
Fitriani, dkk. Pemberdayaan Ibu Pkk Melalui Pembuatan Jamu Herbal ...

\section{PENDAHULUAN}

Aceh Tamiang sebagai salah satu Kabupaten yang berada di bagian Timur Provinsi Aceh yang berbatasan langsung dengan Propinsi Sumatera Utara. Hal ini mengakibatkan potensi infeksi covid-19 lebih besar dibandingkan dengan Kabupaten lainya. Covid-19 dapat menular melalui kontak langsung dengan penderita dan droplet (percikan). Gejala penyakit ini ditandai dengan demam, batuk kering, dan kesulitan bernapas yang berdampak pada pneumonia dan kegagalan multiorgan. Berdasarkan data dari dinas kesehatan, jumlah OPD, PDP dan positif di Aceh Tamiang terus mengalami peningkatatan yaitu: OPD 13 orang PDP 6 orang dan positif 2 orang. Wilayah ini terdiri dari 12 kecamatan dengan 213 jumlah desa salah satunya yaitu desa Alue Sentang.

Desa Alue Sentang merupakan desa yang berada di Kecamatan Manyak Payed, kabupaten aceh tamiang. Jumlah penduduk mencapai $220 \mathrm{KK}$ yang terdiri dari petani dan nelayan dengan tingkat perekonomian menengah kebawah. Hal ini mengakibatkan daya beli masyarakat terhadap antibiotik dan vitamin rendah, sehingga sangat rentan terhadap serangan virus corona. Selain itu, kurangnya pengetahuan masyarakat tentang dampak yang ditimbulkan jika terinfeksi virus corona. Hal ini mengakibatkan rendahnya kesadaran masyarakat untuk meningkatkan sistem imum tubuh. Oleh karena itu perlu dilakukan upaya untuk mencegah dan memutuskan pemutusan rantai penyebaran virus dengan cara berdiam diri dirumah, menggunakan masker, mengunakan handstinizer, mencuci tangan dengan sabun dan meningkatkan sistem imum tubuh. Peningkatan sistem imum dapat dilakukan dengan mengkonsumsi jamuan herbal yang mengandung berbagai komponen senyawa metabolit sekunder yang baik untuk kesehatan.

Berdasarkan hasil survey dan hasil diskusi dengan Datok Penghulu Desa Alue Sentang bahwa desa ini sangat berpotensi untuk pengembangan jamu herbal, hal ini disebabkan karena ketersediaan bahan baku pembuatan jamu herbal yang melimpah dengan harga yang relatif lebih murah. Jamu herbal terbuat dari berbagai bahan herbal seperti temulawak, jahe, kunyit dan bahan herbal lainya yang mempuyai peran sebagai anti bakteri, antifungi, anti virus virus (Dermawaty, D.E., 2013). Kunyit dan temulawak mengandung curcumin yang mampu meningkatkan sistem imun tubuh. Dalam hal ini Jagetia, G.C dan Aggarwal B (2017) melaporkan bahwa curcumin mampu memodulasi pertumbuhan dan respon seluler dari berbagai jenis sel imun, baik sel $\mathrm{T}$, sel $B$, makrofag, neutrofil, sel NK, dan sel dendritik. Selain itu, Boroumand et al (2018) melaporkan bahwa curcumin berperan sebagai anti inflamasi, antioksidan dan immunomuldulatory pada tubuh. Sedangkan jahe mengandung senyawa fitokimia yang mampu meningkatkan sistem pertahanan tubuh dengan meningkatkan status antioksidan. Dengan besarnya potensi jamu herbal dalam meningkatkan sistem imun tubuh makakegiatan PKM ini diharapkan dapat memberikan konstribusi dalam memutuskan rantai penyebaran virus Covid 19 melalui pembuatan jamu herbal unuk meningkatkan sistem imun tubuh.

\section{METODE}

\section{Lokasi, Waktu dan Durasi Kegiatan}

Lokasi kegiatan dilakukan di

Desa Alue Sentang mulai tanggal 12 Agustus-14 September 2020. 


\section{Alat dan Bahan}

Alat dan bahan yang diperlukan yaitu induk kunyit, temulawak, kencur, gula merah, tepung beras, jahe merah, jahe, daun sereh, daun pandan, cengkeh, air, blender, pisau, kompor, saringan dan lain sebagainya.

\section{Metode Pelaksanaan Kegiatan}

Pelaksanaan kegiatan ini menggunakan metode pendekatan secara langsung meliputi survey lokasi, sosialisasi, ceramah dan praktik.

\section{Survey Lokasi}

Survey lokasi dilakukan di Desa Alue sentang untuk menentukan prioritas kebutuhan masyarakat, sehingga kegiatan yang dilakukan tepat sasaran. Kegiatan survey lokasi ini dilakukan oleh TIM PKM Universitas Samudra.

\section{Sosialisasi}

Sosialisasi dilakukan di desa Alue Sentang yang melibatkan ibu PKK, relawan covid 19 dan aparat desa setempat. Kegiatan ini melibatkan 30 warga masyarakat desa Alue Sentang yang terdiri dari relawan, aparatur desa dan masyarakat. Kemudian peserta akan dibagi kedalam beberapa kelompok dengan tujuan untuk memudahkan proses sosialisasi dan pelatihan.

\section{Pemberian Materi}

Pemberian materi kepada peserta kegiatan dilakukan oleh Tim pelaksanaan kegiatan. Adapun materi yang diberikan yaitu: (1) Keunggulan jamu herbal dalam meningkatkan sistem imum sehinggadapat mencegah infeksi covid 19 dan (2) Tahapan dalam proses pembuatan jamu herbal dan penerapannya dalam meningkatkan sistem imum sehinggadapat mencegah infeksi covid 19

\section{Praktek Lapangan}

Dalam praktek lapangan akan dilakukan proses pembuatan jamu herbal berupa jamu kunyit asam, jamu jakutes, jamu beras kencur, jamu jakutes dan jamu wedang teh jahe

\section{Evaluasi Kegiatan}

Evalusuasi kegiatan dilakukan untuk menentukan keberhasilan pelaksaan pengabdian kepada masyarakat yang telah dilaksanakan. Evaluasi dilakukan dengan melihat kemampuan peserta dalam menerima materi dan membuat jamu herbal.

\section{Teknik Pengumpulan data}

Pengumpulan data dilakukan dengan melakukan observasi secara langsung ke lapangan dan quesioner yang diberikan kepada peserta pada saat sebelum dan sesudah pelaksanaan program pengabdian kepada pmasyarakat.

\section{Teknik Analisis Data}

Analisis data dilakukan dengan pendekatan kualitatif dan quantitatif. Pendekatan kualitatif digunakan untuk menganalisis data hasil obersvasi dilapangan dan pada saat praktik. Sedangkan pendekatan kualitatif dilakukan untuk menganalisis data hasil quesioner yang diberikan pada saat awal dan akhir kegiatan.

\section{HASIL DAN PEMBAHASAN}

Berdasarkan data hasil survey yang dilakukan pada tanggal 12 Agustus 2020 (Gambar 1) di Desa Alue Sentang bahwa banyaknya tanaman TOGA yang berada disekitar perkarangan rumah masyarakat. Namun, tanaman TOGA ini belum dimanfaatkan secara maksimal oleh masyarakat Desa Alue Ie Sentang. Meskipun sudah ada kesadaran dari 
kelompok ibu-ibu PKK untuk mengolah tanaman TOGA menjadi minuman kesehatan seperti jamu. Namun pengolahan TOGA mejadi jamu herbal belum berjalan baik sehingga perlu dilakukan penyuluhan untuk memberikan pemahaman kepada masyarakat akan pentingnya jamu herbal untuk meningkatkan sistem imun tubuh dalam upaya penanggulangan dan pencegahan covid-19 di masa pandemi. Selain itu juga diperlukan pengetahuan dan motivasi yang tinggi untuk menumbuhkan keinginan dan minat masyarakat dalam pembuatan jamu herbal. Pelatihan pembuatan jamu herbal ini bertujuan untuk meningkatkan sistem imun dalam upaya penanggulangan dan pencegahan penularan covid-19 di Desa Alue Sentang. Kegiatan ini terdiri dari serangkaian kegiatan tentang pembuatan jamu herbal yang diharapkan dapat memberikan dampak positif bagi kesehatan dan perekonomian masyarakat Desa Alue Sentang.

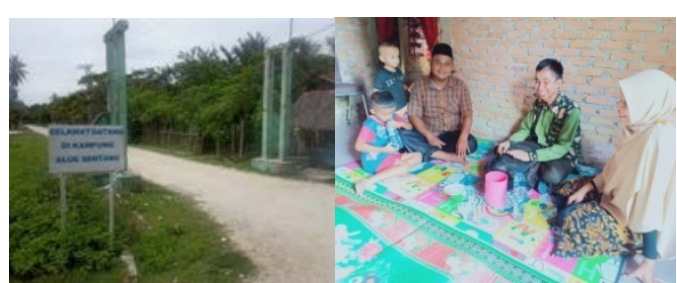

Gambar 1. Survey lokasi kegiatan PKM

Jamu herbal merupakan jamu yang terbuat dari berbagai bahan herbal seperti temulawak, jahe, kunyit dan bahan herbal lainya yang mempuyai peran sebagai anti bakteri, antifungi, anti virus. Hal ini disebabkan karena bahan herbal tersebut (kunyit dan temulawak) mengandung curcumin yang mampu meningkatkan sistem imun tubuh dengan cara memodulasi pertumbuhan dan respon seluler dari berbagai jenis sel imun, baik sel $\mathrm{T}$, sel $B$, makrofag, neutrofil, sel NK, dan sel dendritik. Selain itu, curcumin berperan sebagai anti inflamasi, antioksidan dan immunomuldulatory pada tubuh. Sedangkan jahe mengandung senyawa fitokimia yang mampu meningkatkan sistem pertahanan tubuh dengan meningkatkan status antioksidan

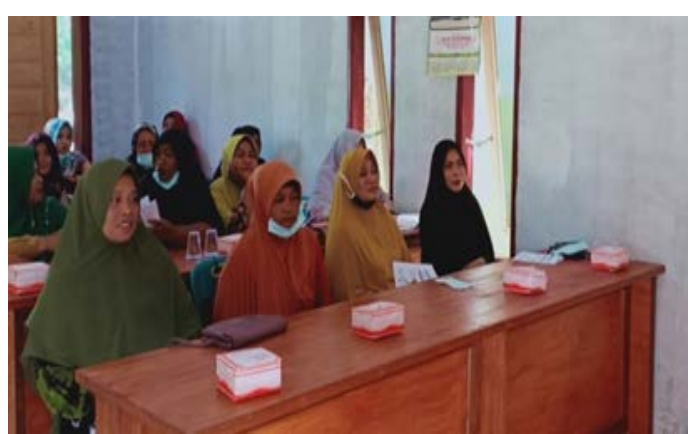

Gambar 2. Sosialisasi Kegiatan Pengabdian Kepada Masyarakat

Berdasarkan hasil sosialisasi dan diskusi dengan Kelompok Ibu PKK dan Aparatur pemerintahan di Desa Alue Sentang yang dilakukan pada tanggal 15 Agustus $2020 \quad$ (Gambar 2), menunjukkan bahwa antusias masyarakat sangat tinggi mengenai program pengabdian masyarakat dalam pembuatan jamu herbal untuk meningkatkan sistem imun dalam upaya menanggulangi dan mencegah penularan Covid 19. Hal ini disebabkan karena adanya rasa kekhawatiran masyarakat akan penularan virus covid 19 yang dapat menular melalui kontak langsung dengan penderita dan droplet (percikan) yang berdampak pada pneumonia dan kegagalan multiorgan sehingga mengakibatkan kematian. Selain itu, juga disebabkan karena kegiatan ini nantinya akan menghasilkan produk jamu herbal yang dapat dipasarkan sehingga dapat meningkatkan perekonomian masyarakat di tengah wabah pandemi virus corona.

Pelaksanaan pelatihan Kegiatan Pengabdian Kepada Masyarakat (PKM) dilaksanakan pada tanggal 18Agustus 
2020 (Gambar 3). Pelaksanaan kegiatan PKM didahului dengan pemberian buku panduan kegiatan pembuatan jamu herbal kepada peserta kegiatan dengan tujuan untuk mempermudah saat pelatihan kegiatan. Buku panduan tersebut berisi tentang alat-dan bahan yang digunakan serta tata cara pembuatan jamu herbal. Selanjutnya dilakukan kegiatan pemberian materi kegiatan dan praktek lapangan dengan tujuan untuk meningkatkan pengetahuan peserta kegiatan sehingga lebih aplikatif dan interaktif. Untuk mengetahui pencapaian tujuan kegiatan pelaksanaan program pengabdian kepada Ibu PKK dilakukan dilakukan pretest dan posttes di awal dan diakhir kegiatan. Berdasarkan hasil survey tingkat kepemahahaman ibu PKK sesudah dan sebelum diberikan pelatihan, maka dapat di lihat pada Gambar 4

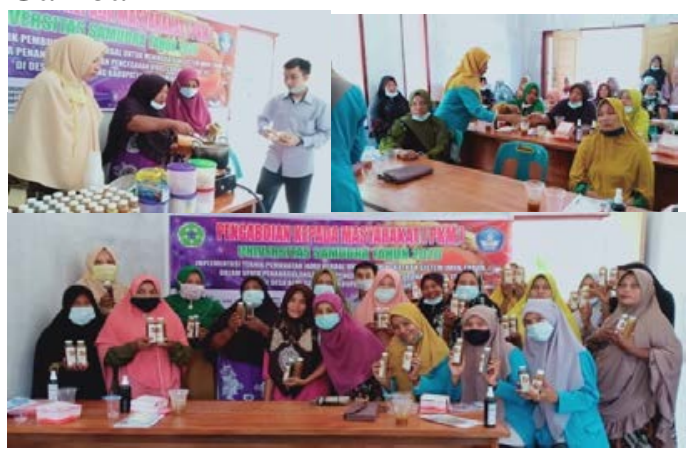

Gambar 3. Pelatihan pembuatan jamu herbal

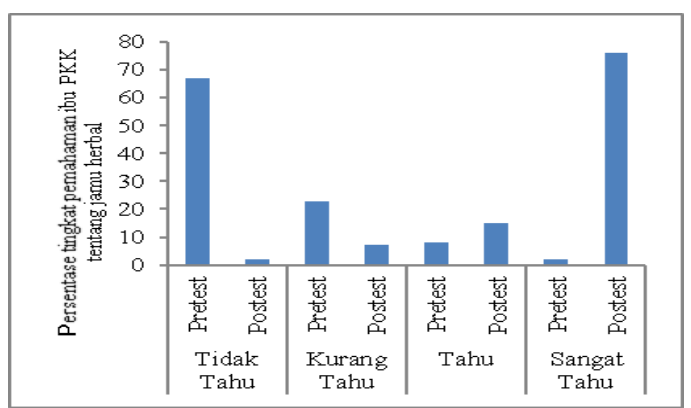

Gambar 4. Persentase tingkat pemahaman ibu PKK tentang jamu herbal

Berdasarkan Gambar 4 menunjukkan bahwa persentase tingkat pemahaman Ibu PPK tentang pembuatan jamu herbal meningkat sebesar $74 \%$ sesudah dilakukan pelatihan kegiatan tersebut. Hal ini dilihat berdasarkan persentase responden yang menjawab sangat tau tentag pembuatan jamu herbal. Hal ini menunjukkan bahwa tingkat daya serap masyarakat tentang materi dan keterampilan tentang pembuatan jamu herbal yang diberikan saat pelatiha cukup tinggi. Selain itu, tingginya antusias masyarakat dalam mengikuti pelatihan pembuatan jamu herbal, hal ini dapat dilihat dengan banyaknya jumlah ibu PKK yang mengajukan beberapa pertanyaan pada saat pelatihan. Dengan demikian dengan adanya program PKM di Desa Alue Sentang ini di harapkan dapat kesehatan dan perekonomian masyarakat.

Evaluasi kegiatan dilakukan setelah semua kegiatan dilakukan. Berdasarkan hasil evaluasi kegiatan ternyata sudah banyak masyarakat yang mulai memanfaatkan tanaman TOGA untuk dijadikan minuman kesehatan seperti jamu dan lain-lainya. Berdasarkan data yang dilaporkan oleh Ketua PKK bahwa terjadinya peningkatkan jumlah produk jamu yang dihasilkan meskipun tingkat pemasaranya masih tingkat lokal dengan meletakkan produk jamu herbal diwarung-warung yang berada di wilayah Desa Alue Sentang. Hal ini diharpakan proses produksi jamu herbal di Desa Alue Sentang semakin meningkat sehingga menjadi sentral produksi jamu herbal di wilayah kecamatan Manyak Payed Kabupaten Aceh Tamiang.

\section{UCAPAN TERIMA KASIH}

Terima kasi kepada Universitas Samudra yang telah memberikan bantuan dana untuk kegiatan 
Fitriani, dkk. Pemberdayaan Ibu Pkk Melalui Pembuatan Jamu Herbal ...

pengabdian masyarakat melalui program pengabdian masyarakat Tahun 2020.

\section{DAFTAR PUSTAKA}

Boroumand, N., Samarghandian, S., Hashemy, S., I. 2018. Immunomodulatory, antiinflammatory, and antioxidant effects of curcumin. J Herbmed Pharmacol. Vol. 7(4): 211-219.

Dermawaty, D.E. 2015. Potential extract curcuma (Curcuma xanthorrizal, Roxb) as antibacterials . Journal Majority. Vol.4(1)

Jagetia, G., C dan Aggarwal, B. 2007. Spicing Up" of the Immune System by Curcumin. Journal of Clinical Immunology, Vol. 27(1) 